\title{
Blockchain Control
}

\author{
Jannice Käll ${ }^{1}$
}

Published online: 30 May 2018

(C) The Author(s) 2018

\begin{abstract}
Blockchain technology is often discussed and theorized in relation to cryptocurrencies such as Bitcoin. Its quality as a technology that produces advanced encryption keys between objects, however, also makes it interesting to those who seek to connect physical objects to digital elements. The reason for this is that the link between objects needs to be 'secure' from undesired external interference. In relation to such interests, blockchain has been identified as a highly attractive technology to support the general digitalization of society towards the Internet of Things, smart cities etc. In extension, the implementation of blockchain technology implies that it may work as a tool that has the capacity to direct which objects may/may not interact with each other. The 'ledger of everything' that blockchain may possibly produce as regards the 'Internet of Everything' is even suggested to make humans and other intermediary technologies redundant. In this essay, I argue that in order to sustain legal critique when the world moves into the next era of digitalization, we need to understand - and question - how technological control operates through e.g. blockchain technology by locking physical and digital elements to each other.
\end{abstract}

Keywords Blockchain $\cdot$ Control $\cdot$ Internet of things $\cdot$ New materialisms $\cdot$ Property

Jannice Käll

jannice.kall@hh.se

1 School of Business, Engineering and Science, Halmstad University, Box 823, 30118 Halmstad, Sweden 


\section{Introduction}

We have moved from the bio-power that Foucault exemplified by comparative anatomy to a society based on the governance of molecular zoe power of today. We have equally shifted from disciplinary to control societies, from the political economy of the Panopticon to the informatics of domination. (Haraway 1991, p. 97)

In the societies of control (...) what is important is no longer either a signature or a number, but a code: the code is a password. (Deleuze 1992, p. 5)

Blockchain technology is often strictly associated with Bitcoin and other types of cryptocurrencies. This is also where such technology by this stage has been put most into use (Swan 2015, p. 9; see also: de Filippi and Hassan 2016). Such discussions have often been accompanied by optimistic accounts on how cryptocurrencies may be a response - and way out - of the capital-based world-order in which we find ourselves (for an overview of some of these discussions, see e.g. Herian 2016a, b). However, blockchain technology is also a general means for much more improved decentralized connectivity between objects through encryption-and by this, as I will argue here, locked-up control over the digitalized worlds that we inhabit.

The rationale behind encryption technologies is to enact openings and closures between different elements through passwords. Successful decryption subsequently opens access between each side of the encryption chain. A basic form of an encryption technology is the regular lock, which produces a barrier between what is inside (e.g. a locker holding paper and books) and what is outside (e.g. a human). For the human to access the elements inside the locker a key needs to be used to unlock the lock. In comparison with a regular lock solution blockchain could be understood as a significantly more advanced lock (see e.g. Herian 2017, pp. 453-460). As it is a digital lock, it can also be added to everything that can be combined with a digital layer.

For this reason, it is unsurprising that blockchain as an encryption technology is now increasingly theorized as a technology that could be utilized to produce locked connections between matter as diverse as persons and persons, persons and things, as well as things and things. This development folds into the transformation of physical things to smart or intelligent things. ${ }^{1}$ As, for example, the magazine Forbes writes, a combination of the development of the Internet of Things (IoT) and blockchain technology makes much sense in terms of improving the encryption needed in IoT. The reason for this is that a substantial part of the data which may be generated through IoT-applications, such as smart home devices, is of personal character. Such data needs to be shared with other machines and services in order to be useful as a smart application. Blockchain technology creates a way to make possible such

\footnotetext{
${ }^{1}$ Herian (2017, pp. 457-458). The division between persons and things is of course problematic in terms of digitalization, see e.g. my doctoral thesis in legal theory: Käll (2017b); and the recent special issue on traditions, myths, and utopias of personhood: Käll (2017a).
} 
sharing in a more secure way as it produces a barrier which a possible malignant actor would need to bypass (Marr 2018).

And furthermore, this folds into a general move of commoditization of information as assets-and property - through digitalization. ${ }^{2}$ As Tapscott and Tapscott argue, through blockchain technology:

physical assets can become digital assets. All documentation relating to a particular 'thing' can be digitized and carried on in the blockchain including patents, ownership, warranties, inspection certification, provenance, insurance, replacement dates, approvals, et cetera. (Tapscott and Tapscott 2016, p. 159)

Through these technologies then, we may soon see an increasing number of layers of digitalization put on 'physical assets' in order to make them both increasingly traceable and more tangible than they ever were without digital layers (Tapscott and Tapscott 2016, p. 159. Also c.f. Herian 2016a, b).

Through the development of such practices, one may furthermore argue that blockchain as a facilitator for the development of smart things - or even environments - appears to move further beyond the always abstract and highly fluent boundaries of what may be commoditized and controlled as property (see e.g. Esposito 2015, p. 1; Käll 2017a). Furthermore, it appears as if this movement of the concept of private property also may be understood as an intensification of how control is pursued through property. The reason for this is that blockchain enables both further digitalization as well as control over physical elements (cars, parcels, entire cities). In this essay, I will build upon new materialist theorists, ${ }^{3}$ to show how such understanding is significant to the form of capitalism in which blockchain is embedded and, furthermore, that this logic in itself dissolves the dominant understanding of property control and human personhood.

\section{Intensification of the Societies of Control}

Digitalization as a process makes possible new logics of domination depicted by both Donna Haraway and Gilles Deleuze as the introductory quotes to this article make visible. Haraway (1991) described the move towards an intensified focus on the treatment of information as a commodity, as a move away from the Foucauldian idea of biopolitics (as a way for the state to control and discipline its citizens) towards an 'informatics of domination'. In this stage, capitalist actors (apart from the state) pervasively control everything and everyone through seizure and control over 'information'. ${ }^{4}$ Deleuze also developed Foucault's idea of control in his famous

\footnotetext{
2 See notably the early example on smart contracts and smart property as described by Szabo (1996).

3 On the scope of this terminology: Dolphijn and van der Tuin (2011), Coole and Frost (2010, p. 5). As argued by Ansell-Pearson, Deleuze utilized this terminology for his theoretical endeavours: AnsellPearson (2017).

${ }^{4}$ Haraway (1991, p. 97), c.f. Hayles (1999) on how cybernetic narratives function to dematerialize elements that traditionally have been perceived as parts of the human body into information.
} 
Post-script on the societies of control. In this text he identified an emerging societal shift where we move from watchwords to passwords (Haraway 1991, p. 97; Deleuze 1992 , p. 5). This could subsequently be interpreted as a move where rules as societal trust-or distrust - are no longer produced through human communication, but rather are dependent on a material regime as a 'password', or a material lock. What both of these writings make clear, furthermore, is that power in a society infused by digitalization may be exercised and distributed on the basis of the actor that has control over the code/script of society.

\section{Blockchain Law or Blockchain (Private) Property?}

It has already been established in the introduction that blockchain as a technology is tightly connected with the potential of pursuing sophisticated encryption. Combining such insight into blockchain with Deleuze's and Haraway's theories about the advancements of the control society furthermore highlights that it is just such kind of practices that pushes society to a new level of control. This type of control implies, as pictured, a codificication of control into the bodies ${ }^{5}$ which inhabit the society. By following such insight, blockchain in fact may function as a mode of (very efficient) law that makes possible or hinders certain enactments. In accordance with the framework of information control discussed above, such control encryption technologies may be understood as displacing or even replacing law as a means for capitalist control. This understanding of blockchain also connects to the insights by Lawrence Lessig, who argued that code already several decades ago was depicted as having the capacity to function as law (Lessig 1999). In light of blockchain technology, one could then even argue that law may be replaced-or displaced—by encryption code as more and more settings become embedded in code.

Primavera de Filippi and Samer Hassan have already pre-empted, and developed, this analogy by stating that what blockchain signifies is a move where law itself becomes code. They build this understanding on the perception that 'law' may be coded into products e.g. through smart contracts (Swan 2015, p. 9; see also: de Filippi and Hassan 2016). This implies that law, or control, which was generally perceived as something outside of both individual humanity and individual things instead may be designed into objects or even entire environments. This type of law embedded into products is a typical effect of automated or 'smart' objects, as the rules for how they communicate with each other are coded into the objects themselves. For such objects, the pace of the technological development makes it difficult to produce law in the common sense of the term to function as an external regulator of how the objects are to communicate. The technology-induced developments of law are however still understood as a fairly neutral (and unstoppable) development in which more and more elements will be connected to ledgers where data is being

\footnotetext{
5 The body is here understood in the broadest sense as all type of matter in coherence with the theoretical frameworks developed by both Gilles Deleuze and Donna Haraway. See e.g. Käll (2017b) and Philippopoulos-Mihalopoulos (2015).
} 
stored and accessed in a more 'secure' way. It has even been suggested that blockchain technologies may function as a replacement of obviously inefficient laws to render personal data increasingly private as we move away from a Facebook/Google era, where information has become increasingly appropriated by large information technology companies. Strengthened privacy through technological solutions could certainly be welcomed in light of the fact that we are now seeing increased legislation as regards private data, not least in the EU setting. ${ }^{6}$ However, what such optimistic accounts of blockchain technologies (as a new type of automatized law) appear to dismiss, is the fact that one may also place the development of automatized code control into the general development of a continuous intensification of proprietary control. The reason for this is that blockchain, as a technology, offers the possibility to code property control into the property objects themselves. When this is done, there is no need to monitor one's property/property rights as such assurance of property rights has become automated. Even though this may not seem to be an extension of property rights per se from a positivist perception of property (if the property right is held in a legitimate manner), the possibility to control something as property certainly becomes enforceable. Furthermore, the development of intensified proprietary control accelerated by digital technologies is no news to anyone who has worked with digitalization, digital contract law and/or intellectual property in the last decade or so. As Professor Margaret Jane Radin forcefully points out, digitalization implies both that information has become tangible and that contract, as a concept within the liberal legal order, has become integrated into the property objects that it governs (see e.g. Radin 2003, 2013).

The integration of the means of control into the property object itself may be identified not least through the now well-advanced discussions regarding Digital Rights Management (DRM), which was introduced to control the digitalization of content such as music, films and video games two decades ago. Such technologies locked the respective types of content to the medium to which it was bundled. In this way, a CD with music was paired with a technology that made it impossible (or rather, difficult) to transfer the music to one's computer (and from there to the online world of sharing said music further). These solutions were also explicitly protected as new forms of property rights in copyright legislation. ${ }^{7}$ As de Filippi and Hassan write, the DRM in this manner came to replace textual/positive law as the means to control the distribution of content. Blockchain technologies may function in the same manner as a means to control property objects, as they may lock different objects in an ecosystem together to each other. The encryption that locks and unlocks objects to a chain makes for automated contracts (just like DRM) to displace positive law by technological means in order to facilitate transactions of different kinds (de Filippi and Hassan 2016). As blockchain technologies now are being utilized as a way to once again control layers of information as well as those

\footnotetext{
${ }^{6}$ C.f. the protection of personal data and the EU directive from a posthumanist perspective in Käll (2017a).

${ }^{7}$ See Schollin (2008); also mentioned as a stage of development towards blockchain as law by de Filippi and Hassan (2016).
} 
layers to which it attaches, this may therefore rather be understood as a variation of a development of control through, and beyond, property law that has already been continuing for decades.

A legal positivist solution to this development could be to call for new legislation or erected boundaries in relation to such developments. Such demand would however entirely ignore the fact that both law and property have been dissolved into a more fluid regime of control as anticipated by both Deleuze and Haraway about 25 years ago. This insight also needs to be read against the common idea that blockchain technologies decentralize power over information networks in a way that could lead to both a less capitalist value system as well as a truly democratic information network (see e.g. Nakamoto 2008). What is notably (dis)missed in such an idea is the fact that advanced encryption follows rather than ruptures the control logics suggested by Deleuze. Subsequently, this logic is utilized to displace authoritative functions within the societal system. As the system that this logic folds under can be described as the 'informatics of domination' following Haraway, this implies that it is capitalist logics, rather than non-hierarchical forms of resistance towards such forces, that will utilize blockchain to strengthen its basis of control. In this way, the logics will be utilized as a means to produce capital. This is not least visible in the way that property concepts are being remodelled to facilitate control over 'intangibles' in digital settings. Furthermore, as also depicted by Deleuze, the development of blockchain technologies, as a kind of technology that decentres law or 'trust' in its previous sense, also implies a thorough production of passwords as a requirement for access between everyone and everything digitally 'enhanced'. What we now witness is that as digitalization unfolds, such entanglement between digital and physical elements will only increase.

\section{Program: The Dissolution of Human Control Over Property}

From a theoretical point of view, the understanding of property rights rests upon an idea of persons as separable from things. ${ }^{8}$ The idea and praxis of property as a means to divide and control societies is today diffused to a large degree worldwide. This holds true in specific to digitalized settings where the 'public' spheres are controlled through layers of intellectual property rights and contracts. Through digitalization processes, this distinction is being increasingly dissolved. The development cited here where 'smart' digital layers or even artificial intelligence turn both things and humans into cyborgs is of specific interest as regards to identifying this evolving regime of control (Haraway 1991, p. 180). As both N. Katherine Hayles and Rosi Braidotti argue, this implies that we now have turned posthuman (Hayles 1999; Braidotti 2013). Following both of these theorists, it is however important to note that this turning posthuman does not occur to everyone or everything, in the same

\footnotetext{
${ }^{8}$ C.f. Esposito (2015). Several fundamental balancing-regimes in property law rest significantly on this assumption still, such as the more or less rigid boundary against commodification of human body parts. See e.g. Bhandar (2012).
} 
way (Braidotti 2013, p. 1). Yet, it is also those who have never been fully human who have most to gain from the turning posthuman, also, of private property. This turn will however not emerge automatically through the 'decentralization' of technological control enacted by blockchain technologies. To think so would be to deny that advanced capitalism continuously produces a 'perverse form' of the posthuman (Braidotti 2013, p. 7). It is already obvious that market actors will utilize blockchain technologies to code and control emerging posthuman spaces. Deleuze expresses this clearly in quoting Félix Guattari as having imagined:

a city where one could be able to leave one's apartment, one's street, one's neighborhood, thanks to one's (dividual) electronic card that raises a given barrier; but the card could just as easily be rejected on a given day or between certain hours; what counts is not the barrier but the computer that tracks each person's position-licit or illicit—and effects a universal modulation. (Deleuze 1992, p. 7)

As of today, such development is now being carried out full-scale. This holds true in more purely digital spheres as well as the emerging smart cities. More or less visible systems that build upon the enactment of passwords are integrated into supposedly control-free spheres. These systems are furthermore bundled with continuous evaluations of one's credibility as a citizen in spaces where digital and physical elements are utilized to keep some bodies in, and others out. The boundaries between property and personhood are in this manner controlled by actors which have direct access to every in/dividual's movement in such a space. Through advanced encryption technologies and decentralization of responsibility, such control may furthermore easily dissolve into a more severe regime of control, which constantly escapes any counter-movement or alternative societal program. For this reason, the development of blockchain urges a reconsideration of the basis for which such technologies can be utilized. In short, it requires a reconsideration of the concept of, and reason for, the mode of proprietary control it enables.

Open Access This article is distributed under the terms of the Creative Commons Attribution 4.0 International License (http://creativecommons.org/licenses/by/4.0/), which permits unrestricted use, distribution, and reproduction in any medium, provided you give appropriate credit to the original author(s) and the source, provide a link to the Creative Commons license, and indicate if changes were made.

\section{References}

Ansell-Pearson, Keith. 2017. Deleuze and new materialism: Naturalism, norms, and ethics. https:// www.academia.edu/20063620/Deleuze_and_New_Materialism_Naturalism_Norms_and_Ethics. Accessed 17 Apr 2018.

Bhandar, Brenna. 2012. Disassembling legal form: Ownership and the racial body. In New critical legal thinking, ed. Matthew Stone, Illan Rua Wall, and Costas Douzinas. Oxon and New York: Routledge.

Braidotti, Rosi. 2013. The posthuman. Cambridge: Polity Press.

Coole, Diana, and Samantha Frost. 2010. Introducing the new materialisms. In New materialisms, ontology, agency, and politic, ed. Diana Coole and Samantha Frost. Durham and London: Duke University Press. 
Deleuze, Gilles. 1992. Postscript to the societies of control. October 59(Winter): 5.

de Filippi, Primavera, and Samer Hassan. 2016. Blockchain technology as a regulatory technology: From code is law to law is code. First Monday 21(12). http://firstmonday.org/ojs/index.php/fm/article/ view/7113/5657. Accessed 17 Apr 2018.

Dolphijn, Rick, and Iris van der Tuin. 2011. Pushing dualism to an extreme: On the philosophical impetus of a new materialism. Continental Philosophical Review 44: 383-400.

Esposito, Roberto. 2015. Persons and things: From the body's point of view, trans. Zakiya Hanafi. Cambridge: Polity Press.

Haraway, Donna. 1991. Simians, cyborgs, and women: The reinvention of nature. New York and London: Routledge.

Hayles, N. Katherine. 1999. How we became posthuman: Virtual bodies in cybernetics, literature, and informatics. Chicago: University of Chicago Press.

Herian, Robert. 2016a. Anything but disruptive: Blockchain, capital and a case of fourth industrial age enclosure-Part I. Critical Legal Thinking 18 October. http://criticallegalthinking.com/2016/10/18/ anything-disruptive-blockchain-capital-case-fourth-industrial-age-enclosure-part/. Accessed $10 \mathrm{Apr}$ 2018.

Herian, Robert. 2016b. Anything but disruptive: Blockchain, capital and a case of fourth industrial age enclosure-Part II. Critical Legal Thinking 19 October. http://criticallegalthinking.com/2016/10/19/ anything-disruptive-blockchain-capital-case-fourth-industrial-age-enclosure-part-ii/. Accessed 10 Apr 2018.

Herian, Robert. 2017. Blockchain and the (re)imagining of trusts jurisprudence. Strategic Change: Briefings in Entrepreneurial Finance 26(5): 453-460.

Käll, Jannice. 2017a. A posthuman data subject? The right to be forgotten and beyond. German Law Journal 18(5): 1145-1162.

Käll, Jannice. 2017b. Converging human and digital bodies-posthumanism, property, law. Doctoral Thesis, Gothenburg University.

Lessig, Lawrence. 1999. Code and other laws of cyberspace. New York: Basic Books.

Marr, Bernard. 2018. Blockchain and the internet of things: 4 important benefits of combining these two mega trends, Forbes 28 January. https://www.forbes.com/sites/bernardmarr/2018/01/28/blockchain -and-the-internet-of-things-4-important-benefits-of-combining-these-two-mega-trends/2/\#6cbb7 0c512dd. Accessed 10 Apr 2018.

Nakamoto, Satoshi. 2008. Bitcoin-A peer-to-peer electronic cash system. 1 February. https://bitcoin.org/ bitcoin.pdf. Accessed 10 Apr 2018.

Philippopoulos-Mihalopoulos, Andreas. 2015. Spatial justice: Body, lawscape, atmosphere. Abingdon: Routledge.

Radin, Margaret Jane. 2003. Information tangibility. In Economics, law and intellectual property: Seeking strategies for research and teaching in a developing field, ed. Ove Granstrand. New York: Springer Science and Business Media.

Radin, Margaret Jane. 2013. Boilerplate, the fine print, vanishing rights, and the rule of law. Princeton: Princeton University Press.

Schollin, Kristoffer. 2008. Digital rights management: The new copyright. Stockholm: Jure Förlag AB.

Swan, Melanie. 2015. Blockchain: Blueprint for a new economy. Sebastopol, CA: O’Reilly Media Inc.

Szabo, Nick. 1996. Smart contracts: Building blocks for digital markets. Previously published in slightly revised form in Extropy 16. http://www.fon.hum.uva.nl/rob/Courses/InformationInSpeech/CDROM /Literature/LOTwinterschool2006/szabo.best.vwh.net/smart_contracts_2.html. Accessed 10 Apr 2018.

Tapscott, Don, and Alex Tapscott. 2016. Blockchain revolution: How the technology behind bitcoin is changing money, business, and the world. New York: Penguin Random House. 